\title{
Jubilee of Johns Hopkins Hospital
}

"L ET us hope," said John Shaw Billings at the opening on May 7, 1889, of the Johns Hopkins Hospital in Baltimore, "that before the last sands have run out from beneath the feet of the years of the nineteenth century, it will have become a model of its kind, and that upon the centennial of its anniversary it will be a hospital which shall still compare favourably, not only in structure and arrangement, but also in results achieved, with any other institution of like character in existence."

Half a century has rolled by sinco that memorable day, full of pride, tradition, and famous men whose names continue to shine with undiminished brightness in the medical firmaments: Osler, Welch, Halsted, and Kelly. The intellectual child of that wealthy Baltimore bachelor and banker John Hopkins, when the hospital opened its doors, it consisted of seventeen buildings with two hundred and thirty beds, seven graduate head nurses, and seventeen probationers. There were but four services : medical, surgical, gynæcological, and pathological. To-day "Hopkins" has developed into a medical centre with 1,024 beds and 590 nurses.

On May 4, 5, and 6 a large number of old Hopkins people, medical men and nurses, and many distinguished visitors gathered together at Baltimore to celebrate the fiftieth birthday of an institution of which it has been said that it has become more famous than the historic city beyond its walls. At the exercises held on the green lawn of the hospital on the afternoon of May 4, Dr. James B. Herrick, "dean of American physicians", described Osler's text-book of medicine as Johns Hopkins's greatest single contribution to medicine. A serious note was struck by the Hospital's director, Dr. Winford $H$. Smith, who suggested that the days of great individual fortunes are passing and with them the days of great philanthropies and benefactions, so that one of the prime problems of the hospital of the future will be increasing dependence upon Government for support. In the evening a historical play, "The Flowering of an Idea", written by Dr. Alan M. Chesney, dean of the Medical School, and dealing with the early development of the Hospital, was performed.

A carefully planned and fascinating programme consisted of exhibits, lectures, demonstrations, and conferences. Among others, Dr. Simon Flexner spoke on "The Nuffield Benefaction and the FullTime Chairs at Oxford". At a reunion dinner attended by some thousand medical men and nurses, Dr. J. M. T. Finney acted as toastmaster, and the speakers included Dr. Howard A. Kelly, the only surviving member of the "Big Four" immortalized in Sargent's painting, and Dr. Lewellys F. Barker.

The eyes of the scientific world will be focused upon Johns Hopkins Hospital during the next fifty years of its existence. It has had a great past, and its responsibility towards the future is enormous beyond reckoning. "A city that is set on a hill cannot be hid.'

WALTER BetT.

\section{Scientific and Industrial Research in Australia}

$\mathrm{T}$ HE twelfth annual report of the Council for Scientific and Industrial Research, Commonwealth of Australia, covers the year ended June 30, 1938.*

The most important development during the year was the decision of the Government to extend the work of the Council for the secondary industries, for which purpose the sum of $£ 250,000$ was appropriated for capital expenditure, involving establishment of the Standards Laboratory and an aeronautical and engine testing laboratory and an information section. A site has been offered by the University of Sydney for the Standards Laboratory within its own grounds. It is proposed that the laboratory should be organized in sections for meteorology, electro-technology and physics. The aeronautical laboratory is to be located in Melbourne, for which purpose a site has already been acquired. In addition to providing the information service visualized by the Secondary Industries Testing Research Committee, the proposed information section is intended to initiate research work in co-operation with industry, and the Imperial Agricultural Bureaux plan will be extended to include other branches of science and industry than agriculture.

* Parliament of the Commonwealth of Australia. Twelfth Annual Report of the ('ouncil for Scientific and Industrial Research for Year 1937-38. Pp. 96. (( anberra: Government Printer, 1939). 48.
In addition to the preparation of bibliographical references, the work of the section will cover the supply of scientific and technical information, the preparation of information relating to recent advances in the application of science to industry, etc., the preparation and publication of articles, Press state. ments, reports, etc.

The report gives brief reviews of the work carried out by the various departments of the Council. The Division of Plant Industry has continued its work on the breeding of pasture plants, the storage of fruit and on the root rot of wheat. Tobacco investigations have included the control of downy mildew, and a survey is being made of the potato virus diseases of Australia.

The work of the Division of Economic Entomology during the year on the sheep blowfly pest has been concerned with the study of attractiveness, the development of standard methods of testing poisons and investigations of dressings. Further work has been carried out on the control of codling moth with the particular object of finding an efficient alternative to lead arsenate.

The Division of Animal Health and Nutrition occupied the new animal health research laboratory at Melbourne during the year, and work on pleuro. 